\title{
The Influence of Government Regulation on IPO Underpricing
}

\author{
Lei Li \\ School of Economics, Jinan University, Guangzhou, China \\ Email: lil@cdcfund.com
}

How to cite this paper: Li, L. (2018) The Influence of Government Regulation on IPO Underpricing. Technology and Investment, 9, 109-116.

https://doi.org/10.4236/ti.2018.92008

Received: April 8, 2018

Accepted: May 20, 2018

Published: May 23, 2018

Copyright $\odot 2018$ by author and Scientific Research Publishing Inc. This work is licensed under the Creative Commons Attribution International License (CC BY 4.0).

http://creativecommons.org/licenses/by/4.0/

\begin{abstract}
The IPO in China has been subject to the audit system, which imposes strict control over the pace of issuance of new stocks. The issuance of new stocks is relatively small, and there are also various restrictions on the issuance prices. High IPO underpricing rate and high turnover rate have always been unique to China's new issue market. For this reason, this article begins with the causes of the high underpricing rate, and combines investor sentiment to study the effect of the new share issuance system on the IPO underpricing rate.
\end{abstract}

\section{Keywords}

IPO Underpricing, Government Regulation, Investor Sentiment

\section{Introduction}

The underpricing rate is used to measure the difference between the issue price and the closing price on the first day of the listing. Usually it is defined as the ratio of the difference between the closing price and the issue price. For a long time, China's IPO underpricing has attracted many researchers. That the underpricing rate is much higher than that of the developed countries is inextricably linked with the government regulations. At the same time, the structure of investors in China's securities market is also quite different from that of developed countries. After undergoing several major changes in China's new stock issuance system, the level of marketization has significantly increased, significantly reducing the IPO underpricing rate. However, at present, the reform of the new share issuance system is still in a difficult state. This paper hopes to examine the role of government, underwriters, institutional investors, and individual investors in the market during the development of the stock market in China in the past two decades and discuss the formation mechanism of the underpricing rate 
of new stock offerings in China. I hope it meaningful for the reform of the new share issuance system in the future.

\section{Literature Review}

IPO underpricing was discovered in 1969, attracting many researchers and forming a wealth of theory. Reilly and Hatfield studied a small sample from 1964 to 1965 in 1969 and found significant evidence of excess returns to IPO. Then, Rock (1986) applied Winner's Curse Hypothesis to the interpretation of IPO underpricing [1]. He believes that there are predominant investors and inferior investors in the market. Dominant investors will squeeze out inferior investors when the issuance status is good, and exit the issue when the issue status is poor. In order to attract disadvantaged investors to participate in the issuance, the issuer must discount the price of the stock. Allen and Faulhaber proposed the signal transmission theory in the working paper of Pennsylvania University in 1987 [2]. The signal transmission theory divides the companies in the market into promising companies and companies with no prospects. Prospective companies will pass on the company's high-quality information to investors through depressing the issue price, and will be rewarded in subsequent releases. Unpredictable companies will not be able to achieve the level of underpricing that prospective companies can achieve due to signal costs. Gongmeng Chen and Ning Gao (2000) and later researchers examined the applicability of the traditional Western theory of underpricing to China's stock issuance market and found that the traditional Western theory of underpricing has partial applicability to China's stock issuance market [3].

In 1990, Carter and Manaster put forward the hypothesis of investment bank credit [4]. He believes that the credibility of investment banks is a signal to judge the risk of issuance of stocks, and high-reputation investment banks are less risky to underwrite stocks and have a lower degree of underpricing. Hong Guo and Zhenyu Zhao believe that the reputation of the underwriter has no effect on the issue price and initial return, but it has a significant positive correlation with the long-term return of the IPO company [5].

Ritter (1991) studied the data listed in the United States from 1975 to 1984 and found that these newly-listed companies did not perform well in the same industry after the listing for three years [6]. Research shows that investors may be overly optimistic about the future growth of the company. The difference between the offering price and the first-day closing price may not be caused by the primary market price reduction but by the secondary market premium. Liyan Han and Yanran Wu (2007), after analyzing the theory of underpricing and premium theory, believe that the premium theory is more suitable for China's national conditions [7]. More researchers believe that the high price-reduction rate in China's stock issuance market is caused by investor sentiment.

Researchers try to explain the underpricing phenomenon from China's special conditions. Chi and Padgett found that China's IPO average underpricing rate 
from 1996 to 2000 was 129.16\%, suggesting that China's IPO underpricing rate was mainly caused by the imbalance in supply and demand caused by the quota system [8]. Lihui Tian (2011) used the supply and demand model to analyze the phenomenon of extreme underpricing in China's stock market. He proposed that the Chinese government's intervention in IPO pricing and control of stock supply is a decisive factor in the extreme underpricing rate in the Chinese stock market [9].

Foreign scholars began to study the phenomenon of underpricing very early, and the related theories formed were relatively complete. Related models are also comprehensive. The hypothesis that the information asymmetry theory is based on the premise that the secondary market is effective, but the effectiveness of the secondary market of China's stock market is generally questioned. More and more research shows that the high price of new stock issuance in China should actually be interpreted as a high premium, that is, the secondary market is overvalued, rather than the primary market valuation is too low. Secondly, due to China's strict control over the price, issuance size and pace of stock issuance, the supply of new stocks in the primary market is insufficient. This is the fundamental reason for the excess returns on the first day of the listing of new shares in China. Due to the lack of supply, China's stock market has a long history of high underpricing. At the same time, due to the large number of retail investors in China, the phenomenon of investor sentiment is more serious, resulting in a unique high underpricing rate and high turnover rate.

After studying the direct influence of government regulation, this paper further explains the influence of institutional factors on the IPO underpricing in China from the perspective of investor sentiment. It is hoped that the study of this paper will provide some inspiration for the promotion of the future IPO registration system.

\section{The Influence of Government Regulation on IPO Underpricing}

\subsection{Impact of New Share Offering System}

The impact of new share issuance system on the IPO underpricing can be analyzed from the three dimensions of quantity, price and distribution.

First, the regulatory system of China's stock issuance has greatly affected the number of stocks listed. As a special commodity, the lack of supply of stocks will inevitably cause the high price of the secondary market in China. Research on related literature also answered this question more clearly.

Second, in order to protect the interests of investors, the government has stricter price controls on the issuance of new shares. The pricing system of China's stock issuance uses administrative pricing in the early stage and lacks a market price formation mechanism. Later, a more market-based inquiry system was adopted, and there is still a underlying price limit of 23 times P/E. The suppression of the issuance price of new shares is also one of the important factors 
that cause the IPO underpricing phenomenon in China to remain relatively serious.

Third, China's stock offering system uses more methods for deposit listings, online pricing, offline inquiry + online pricing, and placing to the secondary market. Except for the placing to the secondary market, other placing methods have led institutional investors to take a greater advantage in the issuance process. Due to various restrictions in the IPO market in China, there has been a long period of high optimism. If individual investors are too optimistic about the valuation of new stocks, institutional investors tend to sell stocks on the first day of listing, resulting in the special phenomenon of a high turnover rate and high underpricing rate.

\subsection{The Influence of New Share Issuance System on Investors' Sentiment}

The restrictions on the issuance of new shares and the shortage of stocks are the root causes of IPO underpricing. In this context, there are many small and medium-sized investors in China. These small and medium-sized investors generally lack the ability to make a reasonable valuation of stocks, and they are very vulnerable to the impact of emotions. In the process of participating in the purchase of stocks, the public usually hold greater fool minds, resulting in the stock price being further pushed up. Public investors are important buyers in the market.

\section{Empirical Analysis}

\subsection{Selection of Variables}

The main issue studied in this paper is the formation of the underpricing rate, the underpricing rate $=($ listed first day closing price - issue price $) /$ issue price.

For the selection of independent variables, this paper mainly studies the effect of government regulation on underpricing, and government regulation includes quantity control, price control, issuance rhythm control, and sale method control. The selection of experimental variables is also based on these four aspects as the proxy variable for government regulation. In addition, corresponding control variables are designed based on information asymmetry theory, signal transmission theory and investment bank reputation theory.

Investor sentiment is not only the cause of high underpricing, but also the result of the special investor structure in China. This is an intermediate variable for this study.

The explanation of the explanatory variables selected in this article is summarized in Table 1.

\subsection{The Model of Government Regulation Impact on IPO Underpricing}

Table 2 shows the regression results of the influence of government regulation 
Table 1. Independent variables.

\begin{tabular}{|c|c|c|c|c|}
\hline theory & variables & $\begin{array}{l}\text { Expected } \\
\text { sign }\end{array}$ & equation & Explanation \\
\hline \multirow[t]{3}{*}{$\begin{array}{l}\text { Government } \\
\text { regulation }\end{array}$} & $\begin{array}{l}\text { Allocation rate } \\
(\%)\end{array}$ & - & $\begin{array}{l}\text { Allocation rate }=\text { Actual number of } \\
\text { online distributions/effective online } \\
\text { subscriptions }\end{array}$ & $\begin{array}{l}\text { As the government's proxy variable for quantitative } \\
\text { control, reflecting the supply and demand relationship of } \\
\text { new stocks, the smaller the success rate, the more serious } \\
\text { the phenomenon of new stocks falling short of demand. }\end{array}$ \\
\hline & Price suppression & + & $\begin{array}{l}\text { Price suppression = industry average } \\
\mathrm{P} / \mathrm{E}-\text { the issue } \mathrm{P} / \mathrm{E} \text { of the stock }\end{array}$ & $\begin{array}{l}\text { Reflects the government's control over the issuance } \\
\text { price. The greater the issue price is suppressed, the } \\
\text { higher the underpricing rate of new shares is. }\end{array}$ \\
\hline & Listing time lag & + & $\begin{array}{l}\text { Listing time lag = Initial Listing Day - } \\
\text { Initial Issue Date }\end{array}$ & $\begin{array}{l}\text { The longer the listing holds, the greater the investor's } \\
\text { return, and the higher the underpricing rate. }\end{array}$ \\
\hline $\begin{array}{l}\text { Investors' } \\
\text { sentiment }\end{array}$ & Turnover rate & + & $\begin{array}{l}\text { Turnover ratio }=\text { trading volume on the } \\
\text { first day of listing/tradable shares }\end{array}$ & $\begin{array}{l}\text { It is generally believed that the greater the disagreement } \\
\text { among investors, the higher the exchange rate on the } \\
\text { first day of listing. Due to lack of short-selling } \\
\text { mechanism in the market, resulting in higher prices. }\end{array}$ \\
\hline \multirow[t]{2}{*}{$\begin{array}{l}\text { Information } \\
\text { asymmetry }\end{array}$} & $\begin{array}{l}\text { Total share capital } \\
\text { after issuance }\end{array}$ & - & $\begin{array}{l}\text { Total share capital after issuance }= \\
\text { pre-issuance share capital }+ \text { total issue } \\
\text { amount }\end{array}$ & $\begin{array}{l}\text { After the issuance, the share capital represents the size of } \\
\text { the company. The larger the share capital after issuance, } \\
\text { the lower the degree of information asymmetry and the } \\
\text { lower the underpricing rate. }\end{array}$ \\
\hline & Firm age & - & $\begin{array}{l}\text { Firm age }=\text { release date }- \text { established } \\
\text { date }\end{array}$ & $\begin{array}{l}\text { The larger the firm age, the more information available } \\
\text { to investors, the lower the degree of information } \\
\text { asymmetry and the lower the underpricing rate. }\end{array}$ \\
\hline $\begin{array}{l}\text { Investment bank } \\
\text { reputation }\end{array}$ & Investment bank & - & $\begin{array}{l}\text { Virtual variables, } 1 \text { for famous } \\
\text { investment banks, } 0 \text { for non-famous } \\
\text { investment banks }\end{array}$ & $\begin{array}{l}\text { It is generally believed that high-level investment banks } \\
\text { have higher pricing power and thus lower the level of } \\
\text { underpricing. }\end{array}$ \\
\hline
\end{tabular}

Table 2. Regression analysis of the impact of government regulation on underpricing rates.

\begin{tabular}{|c|c|c|c|c|c|c|}
\hline & Model 1 & Model 2 & $\begin{array}{c}\text { Model } 3 \\
\text { (restrictions on } \\
\text { institutional sales) }\end{array}$ & $\begin{array}{l}\text { Model } 4 \text { (restrictions } \\
\text { on institutional sales) }\end{array}$ & $\begin{array}{c}\text { Model } 5 \text { (No } \\
\text { restrictions on } \\
\text { institutional sales) }\end{array}$ & $\begin{array}{c}\text { Model } 6 \text { (No } \\
\text { restrictions on } \\
\text { institutional sales) }\end{array}$ \\
\hline $\begin{array}{c}\text { Total share capital } \\
\text { after issuance }\end{array}$ & $\begin{array}{c}-1.25 \mathrm{E}-12^{\star *} \\
(5.15 \mathrm{E}-13)\end{array}$ & & & $\begin{array}{c}4.63 \mathrm{E}-13 \\
(5.81 \mathrm{E}-13)\end{array}$ & & $\begin{array}{c}-1.29 \mathrm{E}-11^{*} \\
(6.84 \mathrm{E} 12)\end{array}$ \\
\hline Firm age (days) & $\begin{array}{c}-5.61 \mathrm{E}-5^{\star * *} \\
(2.58 \mathrm{E}-6)\end{array}$ & & & $\begin{array}{c}-2.51 \mathrm{E}-5^{\star * *} \\
(7.97 \mathrm{E}-6)\end{array}$ & & $\begin{array}{c}-1.23 \mathrm{E}-5^{\star * *} \\
(2.9 \mathrm{E}-6)\end{array}$ \\
\hline Listing time lag (days) & & & $\begin{array}{c}0.013^{\star * *} \\
(0.002751)\end{array}$ & $\begin{array}{c}0.013468^{\star * *} \\
(0.002608)\end{array}$ & $\begin{array}{c}0.005^{\star * *} \\
(0.000328)\end{array}$ & $\begin{array}{l}0.00155^{\star * *} \\
(0.000294)\end{array}$ \\
\hline Allocation rate (\%) & & & $\begin{array}{c}-0.03154^{\star * *} \\
(0.00416)\end{array}$ & $\begin{array}{c}-0.01884^{\star * *} \\
(0.004099)\end{array}$ & $\begin{array}{l}-0.0041^{\star * *} \\
(0.001614)\end{array}$ & $\begin{array}{c}-0.01^{* * *} \\
(0.001337)\end{array}$ \\
\hline Price suppression & & & $\begin{array}{c}0.001^{\star * *} \\
(0.000259)\end{array}$ & $\begin{array}{c}0.001024^{* * *} \\
(0.000243)\end{array}$ & $\begin{array}{l}0.001939^{\star * *} \\
(0.000172)\end{array}$ & $\begin{array}{l}0.00105^{\star * *} \\
(0.000145)\end{array}$ \\
\hline Turnover rate (\%) & & $\begin{array}{c}0.003724^{\star * *} \\
(0.000176)\end{array}$ & & $\begin{array}{c}0.007530^{\star * *} \\
(0.000769)\end{array}$ & & $\begin{array}{c}0.004939^{\star * *} \\
(0.000238)\end{array}$ \\
\hline observations & 2540 & 2540 & 725 & 725 & 1815 & 1815 \\
\hline Adjusted $\mathrm{R}^{2}$ & 0.16 & 0.15 & 0.13 & 0.24 & 0.18 & 0.45 \\
\hline
\end{tabular}


on the underpricing rate. The dependent variable is the underpricing rate. Among them, Model 1 tests the information asymmetry theory, which includes the explanatory variables of the Total share capital after issuance and the firm age; model 2 tests the investor sentiment theory, including the explanatory variables of the turnover rate; Model 3 examines the explanatory power of government regulation theory in the case of institutional sales restrictions. The explanatory variables included are the allocation rate, the price suppression, and listing time lag. Model 4 examines the explanatory power of the overall model when there are institutional sales restrictions. Models 5 and 6 respectively explain the explanatory power of government-related variables and overall variables under conditions of no institutional sales restrictions. ${ }^{* * *},{ }^{\star *}$, and ${ }^{\star}$ are significant at the $1 \%, 5 \%$, and $10 \%$ levels, respectively.

Model 1 tests the theory of information asymmetry, and the two variables, namely, Total share capital after issuance and Firm ages, have a significant effect on the underpricing rate, and the signs are also the same as expected. The $\mathrm{R}^{2}$ of the equation is 0.16 , which has certain explanatory power.

Model 2 examines the influence of investor sentiment, and it can be seen that the turnover rate has a significant positive effect on underpricing. The overall $\mathrm{R}^{2}$ of the model reaches 0.15 , which also has certain explanatory power.

Next, we conducted a univariate regression on the reputation of underwriters and also returned the reputation of underwriters in the overall model. However, since the results are not significant, the results of the regression are no longer shown in the article.

Model 3 and Model 5 respectively examine the effect of three agency variables regulated by the government on the underpricing rate in the case of institutional sales and no institutional sales. The empirical results show that the Listing time lag, the price suppression level, and the allocation rate have a significant impact on the underpricing rate, and the symbols are also the same as expected. The overall explanatory power $\mathrm{R}^{2}$ reaches 0.13 and 0.18 , respectively. It also has some explanatory power.

Models 4 and 6 have empirically analyzed the overall model with institutional sales restrictions and no institutional sales restrictions. $\mathrm{R}^{2}$ reaches 0.24 and 0.45 respectively.

In general, in addition to the underwriter's reputation theory, information asymmetry theory, government regulation theory, and investor sentiment theory all have relatively good explanatory powers on the underpricing rate. Considering that information asymmetry is unavoidable in China and other countries, government regulation theory and investor sentiment theory are unique to China. Then the relationship between investor sentiment and government regulation is the following question.

\subsection{Analysis of the Influence of Government Regulation on Investors' Sentiment}

Since most of China's IPOs are allotted in the form of capital lottery. In this case, 
institutional investors have a greater advantage of purchase. Institutional investors used individual investors' optimism to sell their stocks on the first day of listing to obtain excess returns. In addition, the Chinese government has imposed restrictions on certain institutions for a certain period of time. The samples were divided into two groups for analysis. When the institution is restricted for sale within a certain period of time, there is expected selling pressure in the future and the turnover rate will be higher, but the underpricing rate will be lower. When there is no institutional sales restriction period, the underpricing rate is proportional to the turnover rate. Under different placement conditions, the transmission process of underpricing should be different. The following sample will be divided into two groups with institutional sales period and no institutional sales period for research. The relevant explanatory variables are shown in Table 3.

From the perspective of the two sets of data, the larger the Firm ages are, the lower the degree of asymmetry of information, and the disagreement between individual investors and individual investors, individual investors and institutional investors will be relatively small. Firm ages are therefore inversely proportional to the turnover rate. The empirical results are consistent with expectations. In the secondary market, the industry's $\mathrm{P} / \mathrm{E}$ ratio is also proportional to the turnover rate. That is to say, in industries where the secondary market is more optimistic, new stocks are also more likely to form optimism and disagreement among investors. Both groups showed significant and robust results. It also shows a clear inverse relationship between share capital and turnover rate, confirming that small-cap stocks are indeed more likely to be targets of capital speculation. Listing time lag also proves to be inversely proportional to the turnover rate, indicating that the longer the lag, the greater the difference in the psychological state of the buyers and sellers. On the one hand, holders have a greater desire to dispose of their stocks. On the other hand, investors who fail to make purchases are more willing to purchase at higher prices. The expected

Table 3. Regression analysis of investor sentiment.

\begin{tabular}{ccc}
\hline & No restrictions on institutional sales & restrictions on institutional sales \\
\hline Firm ages & $-0.075^{* * *}$ & $-4.81 \mathrm{E}-6^{* *}$ \\
& 0.000224 & $6.95 \mathrm{E}-6$ \\
Industry average P/E & $0.048^{* * *}$ & $0.000214^{* *}$ \\
& 0.014 & 0.000201 \\
Shares in circulation & $-6.91 \mathrm{E}-9^{*}$ & $-3.90 \mathrm{E}-11^{\star *}$ \\
& $3.9 \mathrm{E}-9$ & $1.9 \mathrm{E}-11$ \\
Listing time lag (days) & $0.236^{* * *}$ & $0.000734^{*}$ \\
Allocation rate (\%) & 0.028 & $-0.03789^{* * *}$ \\
Adjusted $\mathrm{R}^{2}$ & $0.54^{* * *}$ & 0.003716 \\
Observations & 0.13 & 0.11 \\
\hline
\end{tabular}


allocation rate should be inversely proportional to investor sentiment, and in the empirical study, the relationship between the allocation rate and the turnover rate is not clear. This is also the deficiency of this study.

\section{Conclusions}

In addition to the theory of information asymmetry, government regulations, including quantity and price, have a large impact on the underpricing rate. In addition, in the Chinese market, since there are more stock investors that are small and medium-sized retail investors, affected by the mood, investors' sentiment has also become an important factor affecting stock underpricing in China's stock market.

In the regression of investors' sentiment influencing factors, it is found that the higher the information asymmetry, the greater the disagreement and the higher the turnover rate. In addition, the smaller the number of tradable shares, the easier it will be for investors to manipulate and the higher the turnover rate. The article combines the industry's further analysis of investors' sentiment and finds that the higher the price-earnings ratio of the secondary market industry, the higher the IPO turnover rate. In other words, over-optimism is common in the industries with higher valuations in the secondary market, leading to over-differentiated opinions on the IPO of the industry. Well the relationship between allocation rate and turnover rate is still not clear.

\section{References}

[1] Rock, K. (1986) Why New Issues Are Underpriced. Journal of Financial Economics, 15, 187-212. https://doi.org/10.1016/0304-405X(86)90054-1

[2] Allen, F. and Faulhaber, G.R. (1989) Signaling by Underpricjng in the IPO Market. Journal of Financial Economics, 23, 303-324. https://doi.org/10.1016/0304-405X(89)90060-3

[3] Chen, G.M. and Gao, N. (2000) Degree and Causes of Underpricing of Chinese Stocks in the Primary Market. Chinese Journal of Finance, 8, 1-12.

[4] Carter, R. and Manaster, S. (1990) Initial Public Offerings and Underwriter Reputation. The Journal of Finance, 45, 1045-1067. https://doi.org/10.1111/j.1540-6261.1990.tb02426.x

[5] Guo, H. and Zhao, Z.Y. (2006) An Empirical Study on the Influence of Underwriter Reputation on IPO Companies' Pricing, Initial and Long Term Returns. Management World, 3, 122-128.

[6] Ritter, J.R. (1991) The Long-Run Performance of Initial Public Offerings. The Journal of Finance, 46, 3-27. https://doi.org/10.1111/j.1540-6261.1991.tb03743.x

[7] Han, L.Y. and Wu, Y.R. (2007) Enigma of Investor Sentiment and IPOs-Underpricing or Premium. Management World, 3, 51-61.

[8] Padgett, C. and Chi, J. (2005) Short-Run Underpricing and Its Characteristics in Chinese IPO Markets. Research in International Business \& Finance, 19, 71-93. https://doi.org/10.1016/j.ribaf.2004.10.004

[9] Tian, L.H. (2010) Financial Regulation, Investment Risk and Excess Underpricing of New Share Issuance. Financial Research, 4, 85-100. 